\title{
The Use of Social Media for Academic Purposes in Student' Learning Process
}

\author{
Elda Tartari \\ Faculty of Education, Aleksander Moisiu University, Durrës \\ eldatartari@gmail.com
}

Doi:10.5901/ajis.2015.v4n2p393

\begin{abstract}
Social media has a great impact on student's lives. They spend a considerable part of their time on these pages. Social media includes social networking sites (SNSs), virtual gaming sites, video sites, projects sites and blogs. Millions of students are using these Web 2.0 tools worldwide, there hasn't been much research regarding the educational use of social networking. The purpose of this study is to investigate attitudes toward the use of social media in learning process. The findings suggest that social media and social network sites in particular can be very useful as an educational tool. Students using SNSs as a supplement to their curriculum showed that they loved spending time on SNSs, and exercises, videos and other sharing in group are useful for their academic purposes. The paper concludes with suggestions for improving academic purpose and it highlights the fact that every educator must regard how their current teaching standard can be improved or how they could perhaps be replaced because of a prevalent web.
\end{abstract}

Keywords: social media, social networking sites, student, learning process

\section{Introduction}

Social media has a great effect on people's lives. The association of social media is the social interaction, which gives the participants the possibility to share opinions, thoughts, and knowledge in a global forum where time and place are insignificant (Carlsson, 2010). A large number of scholars suggest that students learn in new ways using social media and educators should envelop these new platforms (Ito et al., 2009; Jenkins, 2006). In his study O'Keffe et al (2011) claimed that social media platforms allow students to bring together outside of class for the intention of collaborating and exchanging ideas about their homework.

The possible impact of Web 2.0 technologies on language learning process and teaching is in fact revolutionary (Sturm, Kennell, McBride, \& Kelly, 2009; Warschauer \& Grimes, 2007). During the end of the last century many scholar suggested that second language learning/acquisition research has been experiencing a paradigm change, this is moving from a cognitive orientation to a social orientation, from classroom conditions to naturalistic settings, from an appropriation metaphor to a participation metaphor, and from Language second learning to Language second use (Block, 2003; Firth \& Wagner, 1997; Johnson, 2004). The Web 2.0 platform is "a term often applied to a perceived ongoing transition of the World Wide Web from a collection of websites to a full-fledged computing platform serving web applications to end users. It refers to a supposed second-generation of Internet-based services such as social networking sites, wikis, communication tools, and folksonomies that emphasize online collaboration and sharing among users." (Anonymousa, 2007). The researchers, Solomon and Schrum (2007) state that Web 2.0 is "an invented term" and it was used for the first time by Tim O'Reilly in 2004. O'Reilly (2007) reported in his study that services and applications like wikis, weblogs, photo sharing and link sharing highlight the social aspects of a Web 2.0 world. The technology and Web 2.0 tools are encouraging of knowledge construction, immersion in a foreign language, and interactivity through sites. Shih \& Yang, (2008) also claimed that through technology experiences, language learners are able to interact with others, confront virtual reality collaboratively, expand their knowledge, and establish personal communications. While Harrison \& Thomas (2009) said in their study that the use of social networking sites to learn a foreign language has been little investigated, and the pedagogical assumptions behind their use have been called into question.

Social Network sites are also more and more popular and cause in some of the users a sense of 'flow' (Tufekci, 2008; Vie, 2007). In his research Egbert (2005) shows that this is an experience of losing track of time as a result of being fully engaged in an activity.

Foreign language teaching is both social and inter-active. It means that oral language is learned through social interactions and reading while writing is learned through exposure and guidance from others literate in the target 
language. This makes social networks sites very attractive and possible sites for foreign language practice. If language learners become in the same way involved with SNS activities likewise pedagogically useful foreign language experiences, they might become more motivated and spend more time on the foreign language homework. Social networking can insure tools for teaching in stimulating ways that engage young students so in this academic work and it's going to set out and to examine how social media can help academic purpose.

\section{Literature Review}

For many years, researchers have recognized that networked computers can possibly offer a rich environment for sociocultural language learning. (R. Harrison and M. Thomas; M. J. Jee and M. J. Park, 2009). In this view, G. Blattner and M. Fiori, (2009) stated that Facebook supplies language learning activities, where students can interact and communicate synchronously or asynchronously with native speakers of different languages who share similar interests and have access to an incredible amount of valuable information on a variety of topics. Vygotsky (1978) stated that learning process and language develop through intercommunication with others member of SNS, by means of internalizing problem-solving patterns that are first experienced in dialogue with others.

According to Bakar, "e-learning or web-based learning environment is an evolution in education and English language learning" (Bakar, 2009). Social media can help language acquisition by offering an opportunity to learn through observation before having an understanding. Ryberg, T and Christiansen, E., (2008) claimed that this leads to learners winning confidence and becoming recognized members of the community, which then allows them to stimulate spiritually and allow learning within the community, by being teachers themselves. Sykes et al. (2008) in their study pronounced that the interactive abilities of computer-mediated communication tools has encouraged the study of language learning in text-based chat, massively multiple online gaming and mobile devices.

Bakar declares that students who use Facebook or any e-learning webpage have better reading and writing skills (Bakar et al, 2010). Social identity is accepted as the way English Foreign Language students portray themselves as real persons through interactions; for example, using postings and chatting for swapping ideas about themselves in their foreign language, likewise for recognizing other members in a group. Furthermore, it allows them to represent and negotiate their social presence with other member in a virtual community (Guamán, 2012).

Campbell (2003) in his study represented three particular types of blogs that hold up learning in an English as a Second Language (ESL) classroom:

- Tutor blog: run by a tutor or instructor for the learners which provides daily reading practice; online verbal exchange using comments; provides class information and documents such as a syllabus, and a resource of links for self-study.

- Learner's blog: run by individual students; supports writing practice; develops a sense of ownership; encourages further research; promotes personal expression, and furthers the exchange of ideas.

- Class blog: run collaboratively by the entire class where students can post messages; participate in projectbased language learning; access an international classroom language exchange, and develop a publishing group. (p.3-12)

\section{Research Questions}

Do student use social networking sites as a study source?

Do students improve foreign language skills on social network sites?

What are their attitudes toward the use of social media in academic purposes?

\section{Methodology}

\subsection{Sampling and Participants}

The descriptive research method is used in this study. The study involves $(\mathrm{N}=180)$ respondents which were interviewed with a questionnaire specially designed for this case. This questionnaire aimed to measure the use of social networking sites as a study source and for foreign language learning. The students that participated in this study were $75 \%$ females and $25 \%$ males. They are undergraduate students in the first year of studies, and they are from Tirana. 


\subsection{Instrument}

The instrument was organized into three sections. The first section gathered demographic data, as well as data on how much time they spent on the phone and on the computer, while the second section collected data on social networking sites activities, which can be used as a study source. This section was organized by using the 5-point Likert Scale. In this section students must show the frequency of activities related to social networking sites with the following statements (1= more often and $5=$ never). The third section collected data for elements that support foreign language learning. This section was also organized by using the 5-point Likert Scale. Students were asked to decide at which level they agreed with the following statements ( $1=$ totally disagree and $5=$ totally agree)

\section{Findings and Discussions}

\subsection{Analysis of the Quantitative and Qualitative Data}

One hundred and eighty students $(\mathrm{N}=180)$ formed the subjects of this research. $98.6 \%$ of them use social networking sites and $1.4 \%$ don't use social networking sites because they had no interest in them and use Instagram. Social networking could be accessed by their personal computers or by mobile devices. Students that participated in this study were split between these devices: 80 of them use mobile devices, 43 of them use their smart phones and PCs to access their accounts and 57 of them use only the PCs. $65 \%$ of the students who use social media thought that social networking sites can be successfully used in education to hold up especially foreign language learning.

\subsubsection{The usage of social networking sites as a study source}

Nine questions were constructed to measure this component which gathered information on study usage, information search, asking for help and exchanging homework in Facebook, watch dialogues and tutorials in a foreign language as a practice, sending links and pages for more information about school and studies in general. According to the analysis that came out from the research, we have these percentages: $33.9 \%$ of the students use social media very often as a learning-study tool; $46 \%$ use it often, and $20 \%$ use it very rarely during the study process. There is a week positive correlation between gender and the use of social media $(r=0.2, p<0: 02)$. On the other hand there is viewed a weak negative correlation between spending time on social media and using it as a teaching resource by Pearson $(r=-0.1, p$ $<0: 05$. As a result, we can say that social media is widely used by students to help their study process.

\subsubsection{Improving language skills on Facebook}

$61 \%$ of the students ranked the sections 'agree' to 'totally agree' to express the efficiency of SNSs for improving language skills, namely, grammar, vocabulary knowledge, listening and writing. $16.2 \%$ of them disagreed and $22.5 \%$ were undecided. $90 \%$ of the students listen to music, watch dialogues, short episodes and movies, and text to friends in English language. Only $45 \%$ of the students use social networking sites for grammar and vocabulary knowledge and 55\% of them read information in foreign language.

\subsubsection{Their attitudes toward using social media in academic purposes.}

After transcribing the open question in the instrument of interviews, it was found that the students attitudes towards this activity are very positive, which supports the results of the questionnaire items. The interview results show that students integrate social media into their learning process. Some students expressed that social media plays the important role in foreign language learning while practiced and improved through video sites (as YouTube). Many other students claimed that they always require information on school knowledge in the project sites (as Wikipedia). Some of them had created the blog and spoke often to educational projects. A substantial part of their use social networks to post notices about school, promoting their success in school, practicing foreign language with native speakers and talking with friends often for solving their homework. 


\subsubsection{Class blog}

The same students that participated in the study were also asked to create a class blog to post messages and introduce aspects of Albanian culture in the English language. These activities, in specific, ensure an opportunity to encourage pensive communication in the English language, allowing for the development of writing skills and supplying a framework for context discussion. For their coursework the member were necessary to include suitable information and media about the preferred topic. The topics included Albanian vogue, history, arts, football, Albanian food and Albanian tourist destinations. A minimum of seven posts was necessary. The persons who take part in class blog demonstrate their blogs to the group as part of their graded coursework during week eight of the module. Notes were taken during the student presentations to record participant engagement. A group discussion was select as a means of collecting data on student openness to the social media tool. The participants demonstrated high levels of engagement when presenting the blogs to their friends. Next group discussions argued that they enjoyed develop a publishing group to practice foreign language learning.

\section{Conclusion}

Students in present day use very extensive the social media. Social networks, discussion forums, blogs, wikis, and other technologies have become part of their daily activities. The students had positive attitudes regarding the use of social media as a source of teaching. They use these technologies to improve the learning process. Social media helps them to seeking educational information to complete tasks and develop skills grammar, vocabulary knowledge, listening, writing and reading to learn foreign languages. A considerable part of students use social networks to post notices about school, promoting their success in school, practicing foreign language with native speakers and talking with friends often for solving their homework. At last, when we think through the pedagogical implications of using Web 2.0 and 3.0 tools in foreign language instruction, Jee (2010) claims that there is "...increased authenticity, reduced anxiety with higher motivation, opportunities for learner-centred instruction, enhanced ownership and personal responsibility, significant flexibility in learning preferences and styles."

Every foreign language teachers and every educator should consider how their current paradigms of teaching could be improved or how they may be replaced by these prevalent web. They will be confronted in the feature with these challenges and questions.

\section{References}

Anonymous. (2007, October 21). The all things Web 2.0 directory. Retrieved from http://www.allthingsweb2.com/ (June 5, 2015)

Bakar, N. A. (2009). "E-learning environment: Blogging as a platform for language learning". European Journal of Social Sciences, vol. 9 , no. 4, 584-604.

Bakar, N. A., Latif, H. and Ya"acob, A. (2010). "ESL Students feedback on the use of blogs for language learning 3L; Language, Linguistics and Literature". The Southeast Asian Journal of English Language Studies, vol. 16, no. 1,120-141.

Block, D. (2003). The social turn in second language acquisition. Washington, DC: Georgetown University Press.

Campbell, A. P. (2003). Weblogs for use with ESL classes. The Internet TESL Journal, 9(2), http://iteslj.org/Techniques/CampbellWeblogs.html.

Carlsson, J. (2010, July). An Assessment of Social Media Business. Retrieved from Diploma in Advanced Strategy.University of Oxford (Saïd) Business School: http://www.opengardensblog.futuretext.com/wp-content/uploads/2010/10/Jeanette-Carlsson-AnAssessment-of-Social-Media-Models.pdf

Egbert, J. (2005). Flow as a model for CALL research. In I. J. (Eds.), CALL research perspectives (pp. 129-140). Mahwah, NJ: Lawrence Erlbaum.

Firth, A., \& Wagner, J. (1997). On discourse, communication, and (some) fundamental concepts in SLA research. The Modern Language Journal, 81(3), 285-300.

G. Blattner and M. Fiori. (2009). "Facebook in the language classroom:Promises and possibilities". International Journal of Instructional Technology and Distance Learning, vol. 6. no. 1, 7-28.

Guamán, L. V., (2012). EFL Teenagers' Social Identity Representation in a Virtual Learning Community on Facebook. Universidad Nacional de Colombia, Facultad de Ciencias Humanas, Departamento de Lenguas Extranjeras. Vol. 14, No. 2,182.

Harrison, R. \& Thomas, M., (2009). Identity in online communities: Social networking sites and language learning. International Journal of Emerging Technologies and Society, 7(2), 109-124.

Ito, M., Baumer, S., Bittanti, M., boyd, d., Cody, R., \& Herr-Stephenson, B. (2009). Hanging out, messing around, and geeking out: Kids living and earning with new media. Cambridge: MA: MIT Press.

Jee, M. J. (2010). Web 2.0 technology meets mobile assisted language learning. International Association for Language Learning 
Technology, 41(1), 161-174.

Jenkins, H. (2006). Confronting the challenges of participatory culture: Media education for the 21st century. Chicago: The John D. and CatherineT. MacArthur Foundation.

Johnson, M. (2004). A philosophy of second language acquisition. New Haven, CT: Yale University Press.

M. J. Jee and M. J. Park. (2009). "Livemocha as an online language-learning community". Calico Journal, vol. 26, no. 2, 448-456.

Media, O. (2007). What is Web 2.0: Design Patterns and Business Models for the Next Generation of Software. Communications \& Strategies, No. 1, p. 17.

O'Keeffe, G.S. \& Clarke-Pearson, K. (2011). The Impact of Social Media on Children, Adolescents, and Families. Pediatrics, $28,127$.

R. Harrison and M. Thomas. (2009). "Identity in online communities: Social networking sites and language learning". International Journal of Emerging Technologies and Society, vol. 7, no. 2, 109-124.

Shih, Y-C. \& Yang, M-T. (2008). A collaborative virtual environment for situated language learning using VEC3D. Educational Technology \& Society, 11(1), 56-68.

Ryberg. T and Christiansen. E.,(2008). "Community and social network sites as technology enhanced learning environments". Technology, Pedagogy and Education, vol. 17, no.3, 207- 219.

Solomon, G. \& Schrum, L. (2007). Web 2.0 new tools, new schools. OR: Eugene, International Society fo Technology in Education.

Sturm, M., Kennell, T., McBride, R., \& Kelly, M. (2009). The pedagogical implications of Web 2.0. In I. M. (Ed)., Handbook of research on Web 2.0 and second language learning ( pp. 367-384). Hershey, PA: Information Science Reference.

Sykes, J., Oskoz, A., \& Thorne, S. L. (2008). Web 2.0, synthetic immersive environments, and mobile resources for language education . CALICO Journal, 25(3), 528-546.

Tufekci, Z. (2008). Grooming, gossip, Facebook and MySpace. Information, Communication, and Society, 11, 544-564.

Vie, S. (2007). Engaging others in online social networking sites: Rhetorical practices in MySpace and Facebook. Unpublished doctoral dissertation, University of Arizona, Tucson, AZ.

Vygotsky, L. S. (1978). Mind in society. Cambridge, MA: Harvard University Press.

Warschauer, M., \& Grimes, D. (2007). Audience, authorship, and artifact: The emergent semiotics of Web 2.0. Annual Review of Applied Linguistics, 27, 1-23. 
